\title{
ZMYND8 wt Allele
}

National Cancer Institute

\section{Source}

National Cancer Institute. ZMYND8 wt Allele. NCI Thesaurus. Code C105609.

Human ZMYND8 wild-type allele is located in the vicinity of 20q13.12 and is approximately $148 \mathrm{~kb}$ in length. This allele, which encodes protein kinase C-binding protein 1 , is involved in the function of protein kinase C. The encoded protein is also a cutaneous T-cell lymphoma-associated antigen. 